THIS DOCUMENT CONFIRMED AS UNCLASSIFIED

DIVISION OF CLASSIFICATION

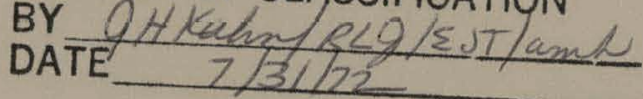

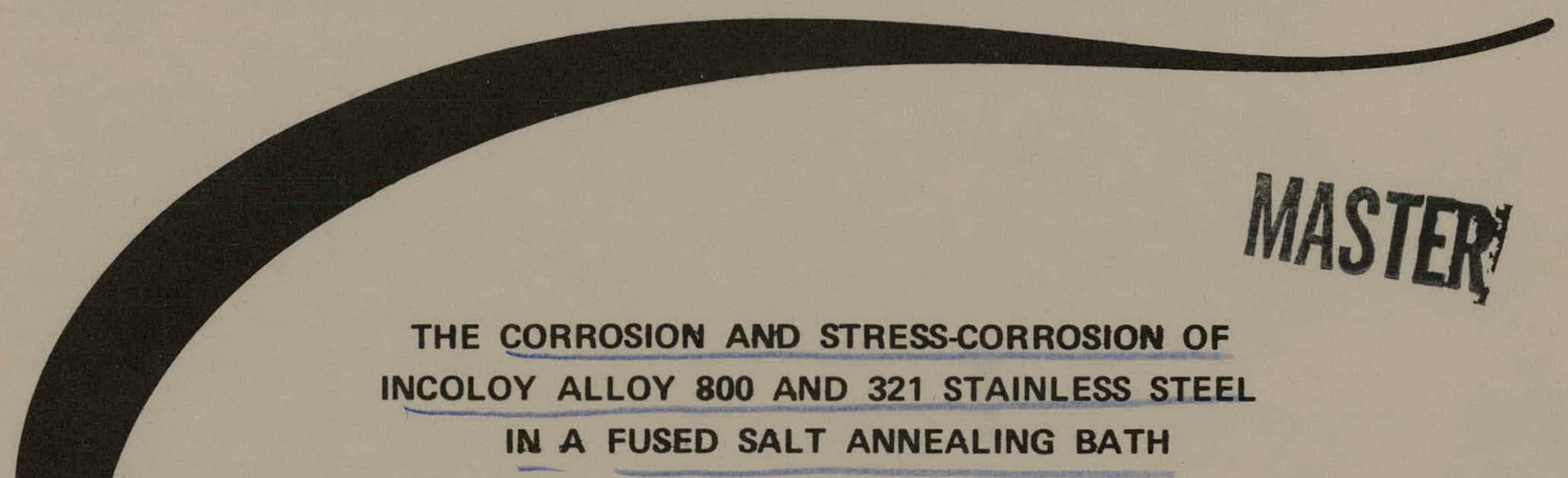

James M. Macki

John L. Briggs

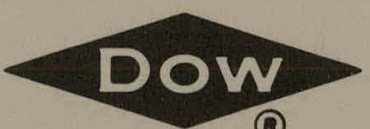

(4)

DOW CHEMICAL U.S.A. ROCKY FLATS DIVISION

P. O. BOX 888

GOLDEN, COLORADO 80401

U. S. ATOMIC ENERGY COMMISSION CONTRACT AT(29-1)-1106 


\section{DISCLAIMER}

This report was prepared as an account of work sponsored by an agency of the United States Government. Neither the United States Government nor any agency Thereof, nor any of their employees, makes any warranty, express or implied, or assumes any legal liability or responsibility for the accuracy, completeness, or usefulness of any information, apparatus, product, or process disclosed, or represents that its use would not infringe privately owned rights. Reference herein to any specific commercial product, process, or service by trade name, trademark, manufacturer, or otherwise does not necessarily constitute or imply its endorsement, recommendation, or favoring by the United States Government or any agency thereof. The views and opinions of authors expressed herein do not necessarily state or reflect those of the United States Government or any agency thereof. 


\section{DISCLAIMER}

Portions of this document may be illegible in electronic image products. Images are produced from the best available original document. 


\section{LEGAL NOTICE}

This report was prepared as an account of work sponsored by the United States Government. Neither the Uniled Slates nor the Uniled States Atomic Energy Commission, nor any of their employees, nor any of their contractors, subcontractors, or their employees, makes any warranty, expressed or implied, or assumes any legal liability or responsibility for the accuracy, completeness or usefulness of any information, apparatus, product or process disclosed, or represents that its use would not infringe privately owned rights.

Printed in the United States of America

Available from the

National Technical Information Service

U. S. Department of Commerce

Springfield, Virginia 22151

Price: Printed Copy $\$ 3.00$; Microfiche $\$ 0.95$ 
Publication Date

June 29, 1972
UC-25 METALS, CERAMICS, AND MATERIALS

TID-4500 (56th Ed.)

\title{
THE CORROSION AND STRESS-CORROSION OF INCOLOY ALLOY 800 AND 321 STAINLESS STEEL IN A FUSED SALT ANNEALING BATH
}

\author{
James M. Macki
}

John L. Briggs

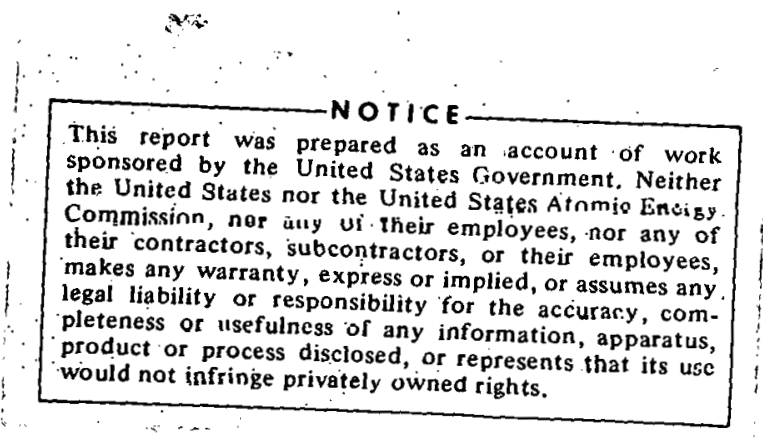

DOW CHEMICAL U.S.A.

ROCKY FLATS DIVISION

P. O. BOX 888

GOLDEN, COLORADO 80401

Prepared under Contract AT(29-1)-1106

for the

Albuquerque Operations Office

U. S. Atomic Energy Commission 


\section{GONTENTS}

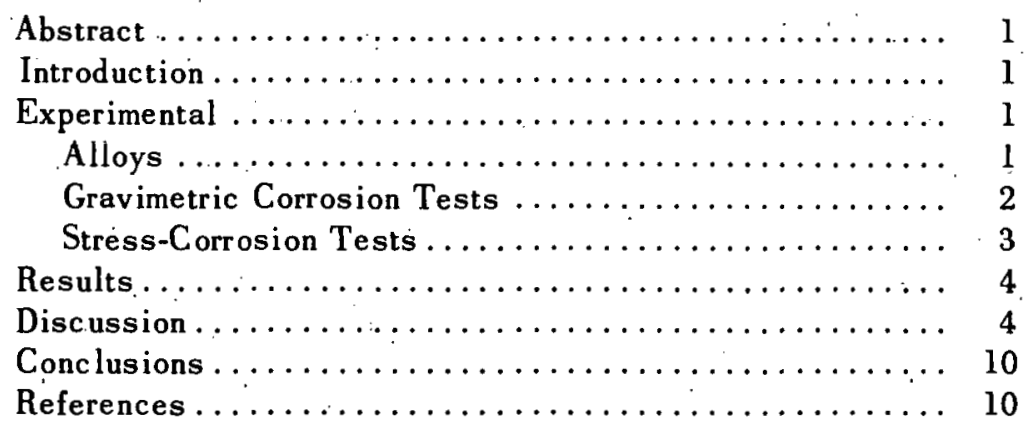




\title{
THE CORROSION AND STRESS-CORROSION OF INCOLOY ALLOY 800 AND 321 STAINLESS STEEL IN A FUSED SALT ANNEALING BATH
}

\author{
James M. Macki and John L. Briggs
}

\begin{abstract}
Corrosion and stress-corrosion tests were performed to select materials for fabricating a tank for holding a fused salt annealing bath $\left(33 \mathrm{wt} \% \mathrm{Na}_{2} \mathrm{CO}_{3}\right.$ $33 \mathrm{wt} \% \mathrm{KCl}$ - $33 \mathrm{wt} \% \mathrm{~K}_{2} \mathrm{CO}_{3}-1 \mathrm{wt} \% \mathrm{MgCO}_{3}$ at $640 \pm 20^{\circ} \mathrm{C}$ ). The corrosion tests involved immersing specimens of ten alloys ( 4340 steel; Hastelloy alloys B, C-276, N, and X; Inconel alloys 600 and 625; Incoloy alloys 800 and 825 ; and 321 stainless steel) in the fused salt for 30 days and determining the gravimetric corrosion rates. The immersion test results showed that 321 stainless steel and Incoloy alloy 800 were superior to the other eight alloys. The stress-corrosion tests involved stressing specimens of these two alloys in four-point bend fixtures and immersing them in the fused salt for 60 days.

Although some carburization and sensitization was observed, no cracking occurred. It was concluded that either 321 stainless steel or Incoloy alloy 800 would be suitable for fabricating the fused salt tank.
\end{abstract}

\section{INTRODUCTION}

During the fabricalion of depleted and en iched uraniun and uranium-base alloys, the metal sheet is annealed by immersion in a fused salt bath. One of the fused salt baths at Rocky Flats uses a mixture of 33 wt\% $\mathrm{Na}_{2} \mathrm{CO}_{3}-33$ wt $\% \mathrm{KCl}-33 \mathrm{wt} \% \mathrm{~K}_{2} \mathrm{CO}_{3}-1$ wt\% $\mathrm{MgCO}_{3}$ at $640 \pm 20^{\circ} \mathrm{C}$.
The present tank used to hold the fused salt is constructed from $3 / 4$-inch thick ASTM-285-69 carbon steel plate $(0.15$ wt\% C - 1.00 wt\% Mn - balance $\mathrm{Fe})$. As specified in the ASTM designation, the steel plate is spray coated with a $\mathrm{Cr}-\mathrm{Al}$ mixture. This coated carbon steel is designated for boiler construction but not for high temperature fused salt service.

The high temperature fused salt environment has rapidly corroded the carbon steel tank resulting in a tank service life of 18 to 24 months. Replacement of the tanks requires a shutdown time of 6 to 8 weeks. The short service life of the carbon steel tank and the lengthy shutdown time have necessitated the selection of a more corrosion resistant material for fabriçating the tanks.

This report describes the corrosion and stresscorrosion tests performed to select a more suitable material for fabricating the fused salt tanks.

\section{EXPERIMENTAL}

\section{Alloys \\ Ten alloys were selected for testing in the fused salt environment. The ten alloys and their nominal compo- sitions are listed in Table 1 .}

Table 1. Certifies Mill Analyses of Corrosion Test Materials (wt\%).

\begin{tabular}{|c|c|c|c|c|c|c|c|c|c|c|c|c|c|}
\hline Alloy & $\mathrm{Ni}$ & Co & $\mathrm{Cr}$ & $\mathrm{Fe}$ & $\mathrm{Cu}$ & Mo & W & Mn & $\mathrm{Si}$ & $\mathrm{C}$ & $\mathbf{S}$ & $\mathrm{P}$ & Other \\
\hline 4340 Steel & 1.76 & - & .78 & $\mathrm{Bal}$ & - & .25 & - & .75 & .27 & .40 & .013 & .008 & \\
\hline Hastelloy B & $\mathrm{Bal}$ & .08 & .02 & 4.95 & - & 27.65 & & .60 & .01 & .02 & .007 & .015 & $V-0.20$ \\
\hline Hastelloy C -276 & Bal & 1.22 & 15.47 & 5.78 & - & 15.72 & 3.52 & .43 & .01 & .012 & .004 & .010 & $V-0$ \\
\hline Hastelloy $N$ & Bal & .07 & 7.52 & 3.97 & .02 & 16.28 & .06 & .52 & .50 & .05 & .004 & .007 & Al \& Ti-0.26 \\
\hline Hastelloy $X$ & Bal & 2.02 & 21.18 & 17.91 & - & 8.90 & .62 & .68 & .74 & .07 & .004 & .015 & \\
\hline Inconel 600 & 77.67 & - & 15.60 & 6.25 & .04 & - & - & 0.20 & .19 & .02 & .007 & - & \\
\hline Inconel 625 & 60.45 & - & 22.81 & 3.28 & - & 9.10 & - & .04 & .21 & .03 & .007 & - & $\begin{array}{l}\mathrm{Ti}-0.30 \\
\mathrm{Nb} \& \mathrm{Ta}-3.64\end{array}$ \\
\hline Incoloy 800 & 31.31 & - & 20.13 & 46.77 & .50 & - & - & .84 & .38 & .04 & .008 & - & \\
\hline Incoloy 825 & 42.33 & - & 20.21 & 30.40 & 1.8 & 3.12 & - & .65 & .26 & .02 & .007 & - & $\begin{array}{l}\text { Al- .12, } \\
T_{1-1.0 b}\end{array}$ \\
\hline $321 \mathrm{SS}$ & 10.80 & - & 17.42 & $\mathrm{Bal}$ & .12 & .30 & - & 1.84 & .56 & .055 & .014 & .018 & Ti-0.53 \\
\hline
\end{tabular}


The 4340 tool steel was tested to simulate the carbon steel now used for the fused salt annealing tanks. The other nine alloys were selected because of the ir corrosion resistant properties in other environments. The properties of the nine alloys are summarized below. These summaries are based on manufacturers' publications.

Hastelloy alloy B is a nickel-molybdenum alloy that was developed primarily for corrosion resistance to hydrochloric acid, but it does possess some high temperature oxidation resistance. In oxidizing atmospheres (not oxidizing solutions) the alloy may be used at temperatures up to $760^{\circ} \mathrm{C}$, and in reducing atmospheres the alloy may be used at higher temperatures.

Hastelloy alloy $\mathrm{C}$ is one of the most universally corrosion resistant alloys available and is resistant to oxidizing and reducing atmospheres up to $1100^{\circ} \mathrm{C}$. The Hastelloy alloy C-276 used in this investigation is an improved wrought version of Hastelloy alloy C. The composition of the two alloys are identical except for the silic on, carbon, and phosphorous contents which are lower in Hastelloy alloy C-276.

Hastelloy alloy $\mathrm{N}$ is a nickel-base alloy that was developed for nuclear reactor applications.

Incoloy alloy 800 is a nickel-iron-chromium alloy that was developed to provide good strength and resistance to oxidation and carburization at elevated temperatures..$^{1,9}$ Because of its high nickel content, Incoloy alloy 800 is resistant to stress-corrosion cracking.

Hastelloy alloy X, Inconel alloy 600 , and Inconel alloy 625 are nickel-base alloys that combine high temperature strength with oxidation resistance up to $1100^{\circ} \mathrm{C}$.

Incoloy alloy 825 is also a nickel-iron-chromium alloy developed for use in corrosive environments. Incoloy alloy 825 resists intergranular attack even in the sensitizing (chromium carbide precipitation) temperature range $\left(650\right.$ to $\left.760^{\circ} \mathrm{C}\right)$. Because of its high nickel content, Incoloy alloy 825 is resistant to chloride ion stress-corrosion cracking. The molybdenum and copper in this alloy provide resistance to pitting and to corrosion by reducing acids. In high temperature applications, Incoloy 825 is usually more scale resistant than the austenitic stainless steels, but it is not as suitable as the Incoloy alloy 800 where resistance to oxidation is required.
Type 321 stainless steel is an austenit ic chromiumnickel (18-8) stainless steel containing titanium. The titanium forms carbides of low solubility which tie up the carbon in the steel and thereby prevent chromium carbides from forming along the grain boundaries (sensitization). Therefore, 321 stainless steel is suitable for service at $430^{\circ} \mathrm{C}$ to $820^{\circ} \mathrm{C}$ where 304 stainless steel would be susceptible to sensitization and intergranular corrosion.

\section{Gravimetric Corrosion Tests}

Duplicate specimens of each of the ten alloys were immersed in the fused salt bath to determine which alloys had the most corrosion resistance to the fused salt environment.

The corrosion specimens were 2.23-inch-diameter disks with 0.33 -inch-diameter center holes. The surface area of each disk was approximately 8 square inches. The thickness of the disks varied depending on the alloy type: the 4340 tool steel disks were 0.25 -inch thick; the 321 stainless steel disks were 0.0625 -inch thick; and all the other alloy disks were 0.031 -inch thick.

Each disk was abraded on a 240-grit silic on carbide belt, cleaned with distilled water, rinsed with acetone, air dried, and weighed to the nearest $0.1 \mathrm{mg}$.

'l'he disks were then mounted on a 316 stainless steel sample holder as shown in F'igure 1. Stainless steel type 304L hanging strips were bolted to the end of each sample holder. The hanging strips were attached to the sides of the fused salt annealing tank. 'l'he length of the hanging strips was adjusted so that each disk was half immersed in the fused salt bath. This positioning of the disks allowed the

Figure 1. Sample Disk Holder.

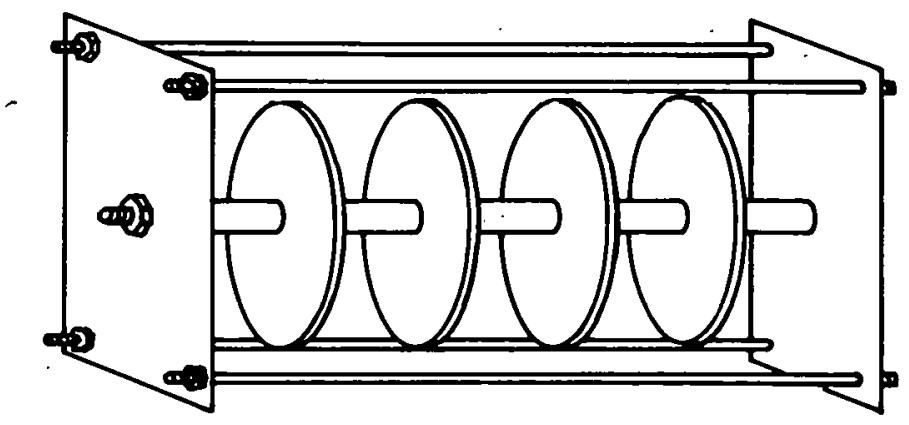


lower part of each disk to be continually immersed. The upper part was immersed only when the fused salt level was raised so that the upper part was alternately immersed as the fused salt level fluctuated. This fluctuation of the fused salt level occurs when uranium sheet material is lowered into the fused salt bath and it is this intermittently immersed area of the tank (at the fused salt-air interface) that has exhibited the severest corrosion attack. The intermittently immersed area is a l-inch-wide band around the tank interior.

All the disks were exposed to the annealing tank environment for 30 days. After 30 days, the disks were removed from the tank and the fused salts, which adhered to the immersed areas of the disks, were removed by dissolution in tap water. Loose corrosion products were removed and the disks were rinsed in distilled water, rinsed in acetone, and air dried. The disks were then re-weighed to the nearest $0.1 \mathrm{mg}$ for corrosion rate determination.

After re-weighing, an Incoloy 800 disk and a 321 stainless steel disk were sectioned and examined metallographically. Because of their excessive corrosion rates, no other disks were examined.

\section{Stress-Corrosion Tests}

The results of the corrosion tests showed that Incoloy 800 and 321 stainless steel had satisfactory corrosion resistance to the fused salt environment. However, the effects of stress on the corrosion resistance was not known. Therefore, four-point bend stresscorrosion tests were conducted using Incoloy 800 and 321 stainless steel specimens.

A bend specimen mounted in a four-point bend stressing device is depicted in Figure 2. The rectangular bend specimens were 5.5 -inches long and 0.75 -inch wide. The Incoloy 800 specimens were 0.130 -inch thick and the 321 stainless steel specimens were 0.123 -inch thick. The distance between the two inner contact cylinders is 2 inches, so that the uniformly stressed region is about 1.5 square inches. This uniformly stressed region is the top, convex surface of the bent specimen between the two inner contact cylinders.

The bend specimen is stressed by advancing the bolt and measuring the deflection of the specimen with the deflection meter as shown in Figure 2. The applied stress is calculated from the specimen

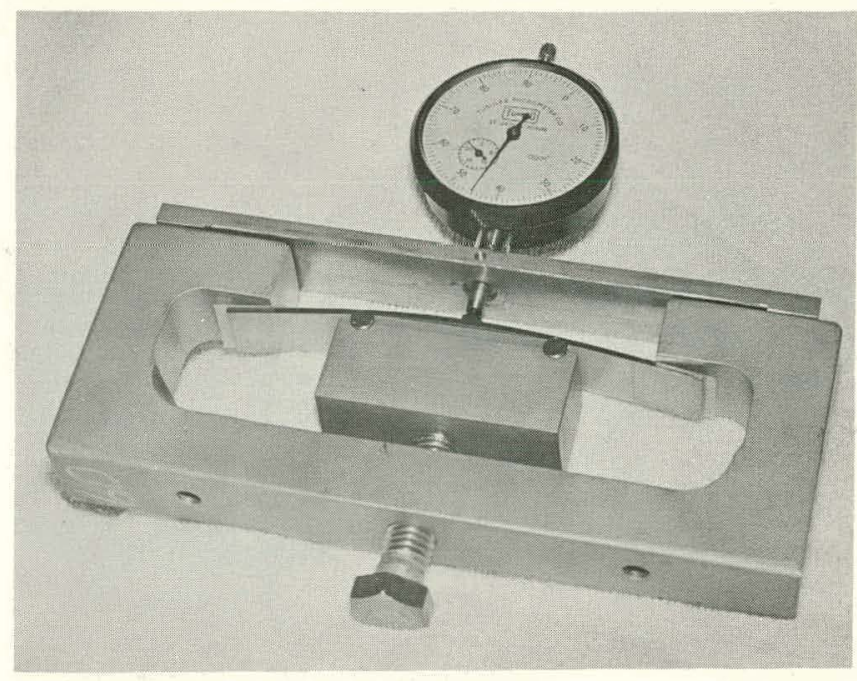

Figure 2. Four-Point Bend Stressing Device. Mylar strips at contact points were not used in the fused salt environment.

dimensions and the geometry of the stressing device using the expression: ${ }^{1}$

$$
\sigma=\frac{12 \mathrm{E} t \delta}{\left[3 \mathrm{~L}^{2}-4 \mathrm{~A}^{2}\right]}
$$

where: $\sigma=$ maximum applied tensile stress (psi)

E - elastic modulus (psi)

$\delta=$ deflection of the mid point of the specimen (inches)

$\mathrm{L}=$ distance between the two outer contact points (inches)

$\mathrm{A}=$ distance between each outer contact point and the adjacent inner contact point (inches)

The applied stress, $\sigma$, is constant over the convex surface of the bent specimen between the two inner contact points. The constant deflection four-point bend test simulates a residual stress condition.

The Incoloy 800 specimens were stressed to a deflection of 0.059 inch. Using $28.5 \times 10^{6}$ psi for the modulus, this deflection corresponds to an applied stress of $60,000 \mathrm{psi}$. The room temperature yield strength $(0.2 \%$ offset $)$ of annealed Incoloy 800 varies between 35,000 psi and 60,000 psi; cold-worked material exhibits yield strengths between 100,000 and 150,000 psi. The Incoloy 800 specimens were in the annealed condition so that some plastic deformation occurred during bending. Therefore, the actual applied stress was probably less than the calculated 60,000 psi applied stress. 
The 321 stainless steel specimens were stressed to a deflection of 0.064 inch which also corresponds to an applied stress of $60,000 \mathrm{psi}$. The yield strength $(0.2 \%$ offset $)$ of the annealed 321 stainless steel is about 35,000 psi. Therefore, plastic deformation would occur in the specimen so that the maximum applied stress would be about 35,000 psi.

At the $640 \pm 20^{\circ} \mathrm{C}$ temperature of the fused salt bath, the actual stresses on the bent specimens would differ from the initial room temperature stresses.

Four stressed specimens of each alloy (Incoloy 800 and 321 stainless steel) were immersed in the fused salt bath, about 6 inches below the fused salt-air interface. After 30 days in the fused salt bath, the eight specimens were removed from the bath, visually inspected for signs of stress-corrosion cracking, and re-immersed in the bath for another 30 days. At the end of the second 30-day period, the specimens were removed from the bath, cooled to room temperature, and the loose corrosion products and salts were removed by immersing the specimens in tap water and gently rubbing the surfaces with a rubber stopper. The specimens were then inspected for cracks. Portions of the stressed mid sections of the specimens were cut out for metallographic examination and bulk carhon analyses.

\section{RESULTS}

The results of the gravimetric immersion corrosion tests in the fused salt bath are summarized in Table 2 and in Figure 3.

Photomicrographs of a cross-section through corroded disks of Incoloy alloy 800 and 321 stainless steel are shown in Figures 4-7 and 8-11, respectively.

Figures 12 and 13 are photomicrographs of two fourpoint bend specimens after 60 days in the fused salt bath. Both figures show transverse cross-sections through the middle, stressed part of the specimen.

The Incoloy alloy 800 and the 321 stainless steel bend specimens that were immersed in the fused salt for 60 days had carbon contents two to three times greater than that in specimens which had not been exposed to the fused salt.
Table 2. Gravimetric Corrosion Test Results after 30 Days Immersion in the Fused Salt Bath. ${ }^{a}$

\begin{tabular}{|c|c|c|}
\hline Alloy ${ }^{b}$ & $\begin{array}{l}\text { Weight } \\
\text { Loss } \\
(\mathrm{mg}) \\
\end{array}$ & $\begin{array}{c}\text { Corrosion } \\
\text { Rate } \\
(\mathrm{mpy})^{\mathrm{c}} \\
\end{array}$ \\
\hline 4340 Steel & $\begin{array}{l}4905.5 \\
5361.5\end{array}$ & $\begin{array}{l}51 \\
56\end{array}$ \\
\hline Hastelloy B & $\begin{array}{l}2068.7 \\
2064.0\end{array}$ & $\begin{array}{l}21 \\
20\end{array}$ \\
\hline Hastelloy C- 276 & $\begin{array}{l}1713.0 \\
2011.9\end{array}$ & $\begin{array}{l}18 \\
21\end{array}$ \\
\hline Hastelloy N & $\begin{array}{l}2149.7 \\
2898.3\end{array}$ & $\begin{array}{l}23 \\
31\end{array}$ \\
\hline Hastelloy X & $\begin{array}{l}379.1 \\
853.3\end{array}$ & $\begin{array}{r}4 \\
10\end{array}$ \\
\hline Inconel 600 & $\begin{array}{l}1182.5 \\
1095.6\end{array}$ & $\begin{array}{l}13 \\
12\end{array}$ \\
\hline Inc onel 625 & $\begin{array}{l}462.2 \\
972.7\end{array}$ & $\begin{array}{r}5 \\
11\end{array}$ \\
\hline Incoloy 800 & $\begin{array}{l}+617.2 \frac{\mathrm{d}}{\mathrm{d}} \\
+607.4 \mathrm{~d}\end{array}$ & \\
\hline Incoloy 825 & $\begin{array}{l}388.8 \\
183.8\end{array}$ & $\begin{array}{l}4 \\
2\end{array}$ \\
\hline 321 Stainless Steel & $\begin{array}{l}203.7 \\
170.3\end{array}$ & $\begin{array}{l}2 \\
2\end{array}$ \\
\hline \multicolumn{3}{|c|}{$\begin{array}{l}\text { a } 33 \mathrm{wt} \% \mathrm{Na}_{3} \mathrm{Co}_{2}-33 \mathrm{wt} \% \mathrm{KCl}-33 \mathrm{wt} \% \mathrm{~K}_{2} \mathrm{Co}_{3}-1 \mathrm{wt} \% \mathrm{MgCo}_{3} \text { at } \\
640 \pm 20^{\circ} \mathrm{C} \text {. } \\
\text { The surface area of the } 4340 \text { steel and the } 321 \text { stainless steel } \\
\text { disks were } 9.25 \text { in }^{2} \text { and } 7.86 \mathrm{in}^{2} \text {, respectively. All of the other } \\
\text { dlsks had surface areas of } 8.10 \mathrm{in}^{2} \text {. } \\
\text { c mpy designates the corrosion rate in mils penetration per year. } \\
\text { d merage weight gain of } 40 \mathrm{mg} \mathrm{dm}-2 \text { day. }\end{array}$} \\
\hline
\end{tabular}

\section{DISCUSSION}

The nickel-base Hastelloy alloys (B, C-276, N, and $X$ ) and the two nickel-base Inconel alloys (600 and 625) displayed poor corrosion resistance to the fused salt environment with average corrosion rates ranging from 4 to $31 \mathrm{mpy}$. Hastelloy alloy $\mathrm{X}$ and Inconel alloy 625 exhibited rates of 4 and 5 mpy, respectively, but the duplicate specimens had rates of 10 and $11 \mathrm{mpy}$, respectively. This poor duplication of corrosion rate measurements was caused by exfoliation (scaling off) of large surface areas as shown in Figure 3 . The Hastelloy alloy disks were attacked more severely along the edges than on the faces of the disks. 

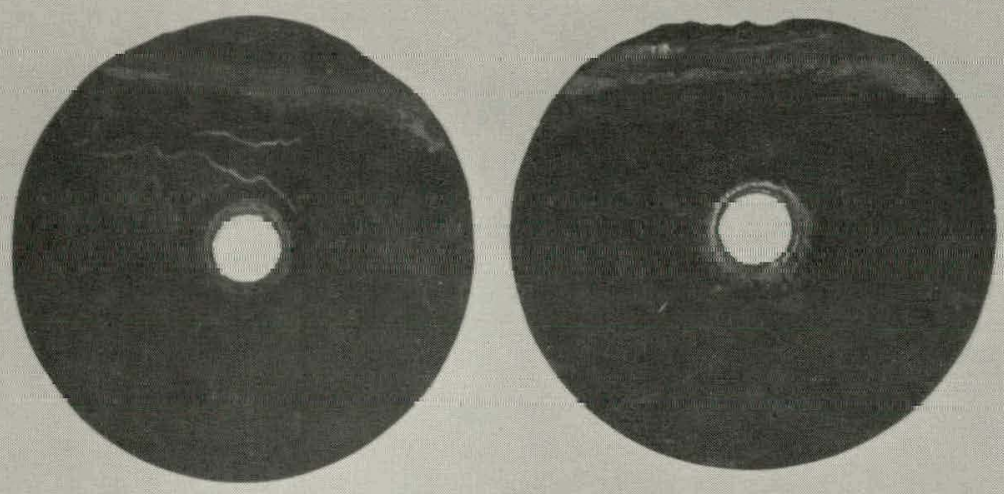

INCONEL 600

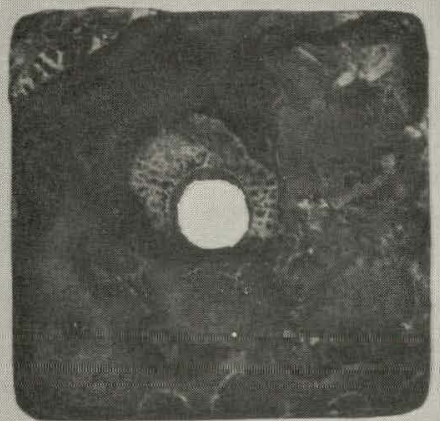

4340 STEEL
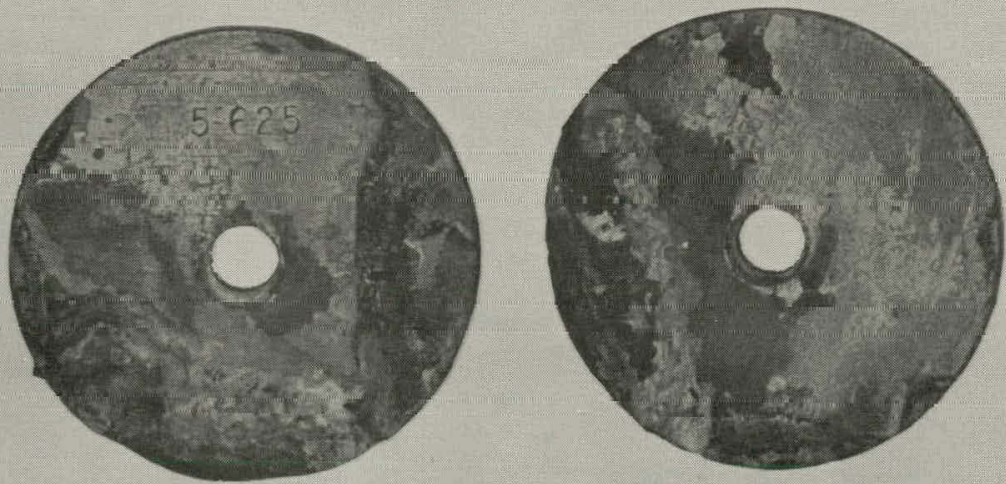

INCONEL 625

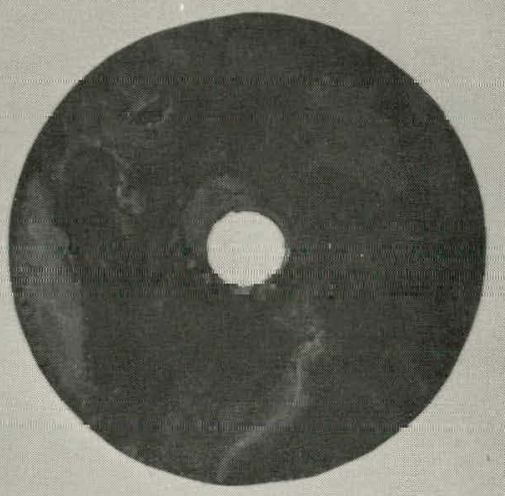

321 STAINLESS STEEL
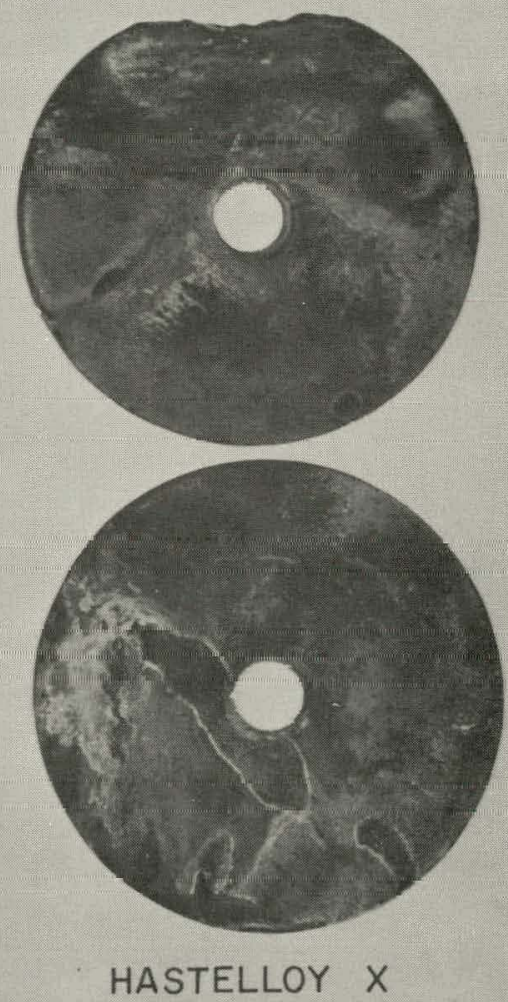

Figure 3. Sample Test Disks After 30 Days Exposure to Fused Salt. 


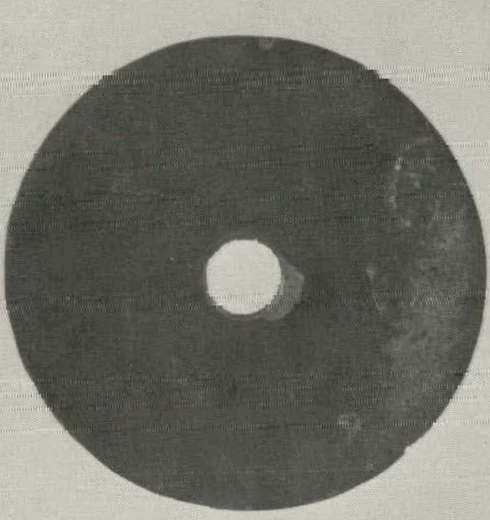

INCOLLOY 800
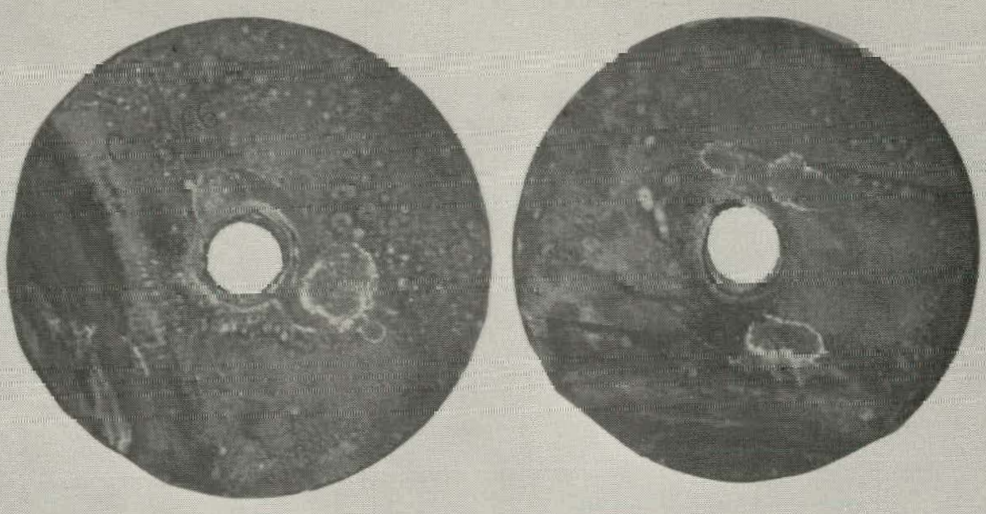

HASTELLOY C

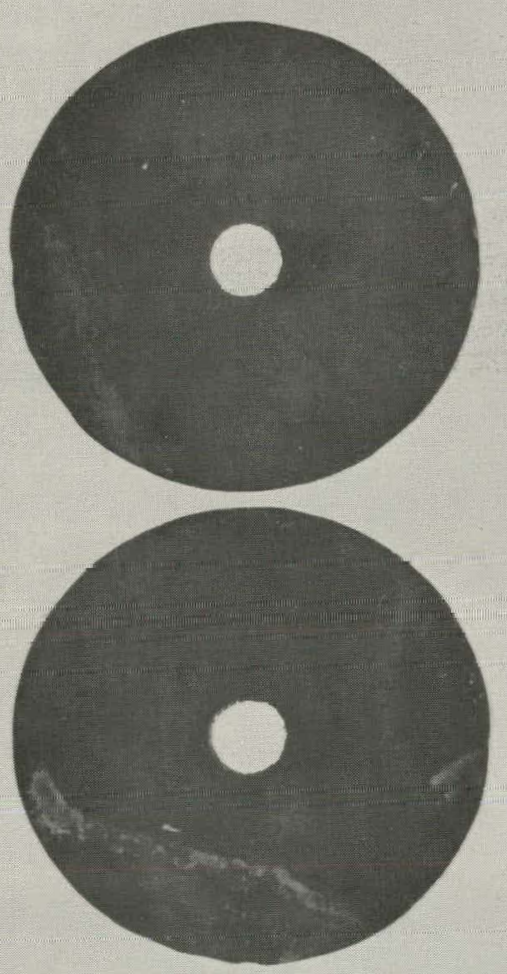

INCOLLOY 825

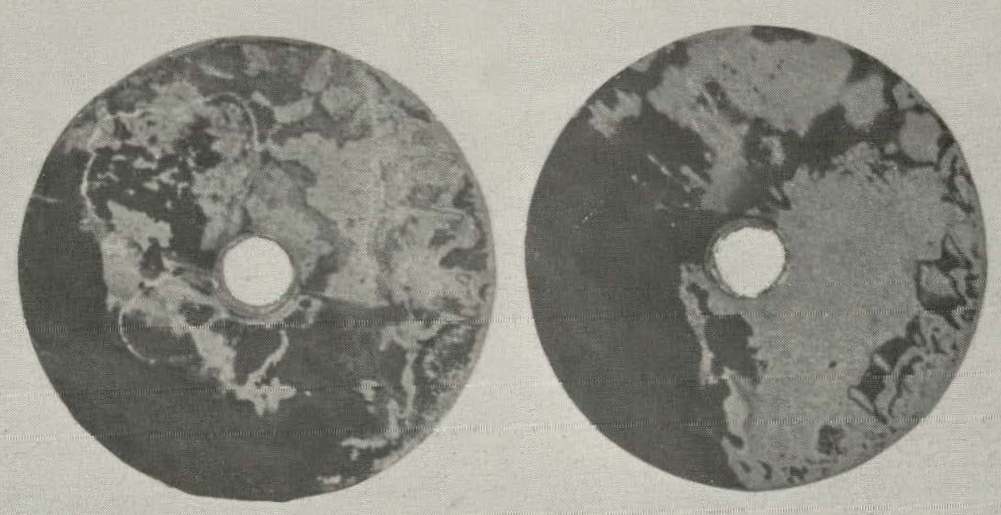

HASTELLOY B

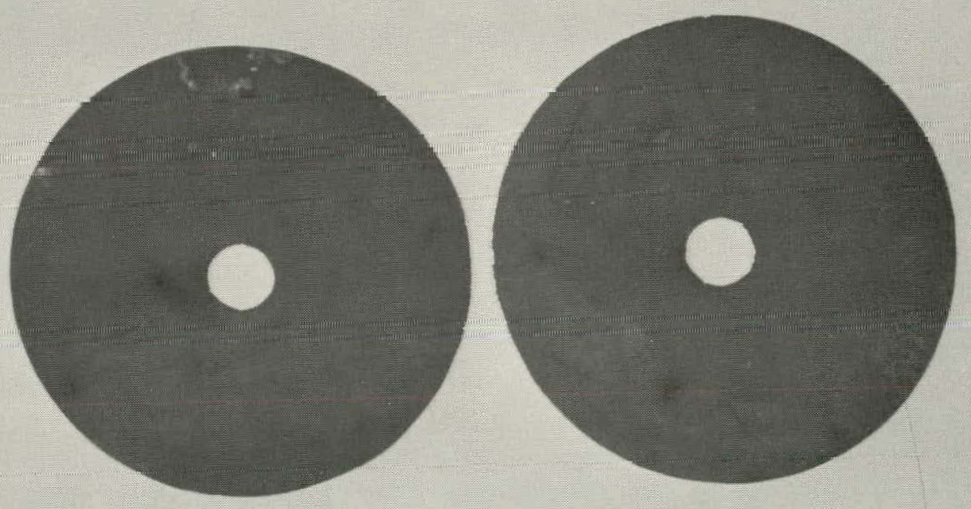

HASTELLOY N

Figure 3 (continued). 


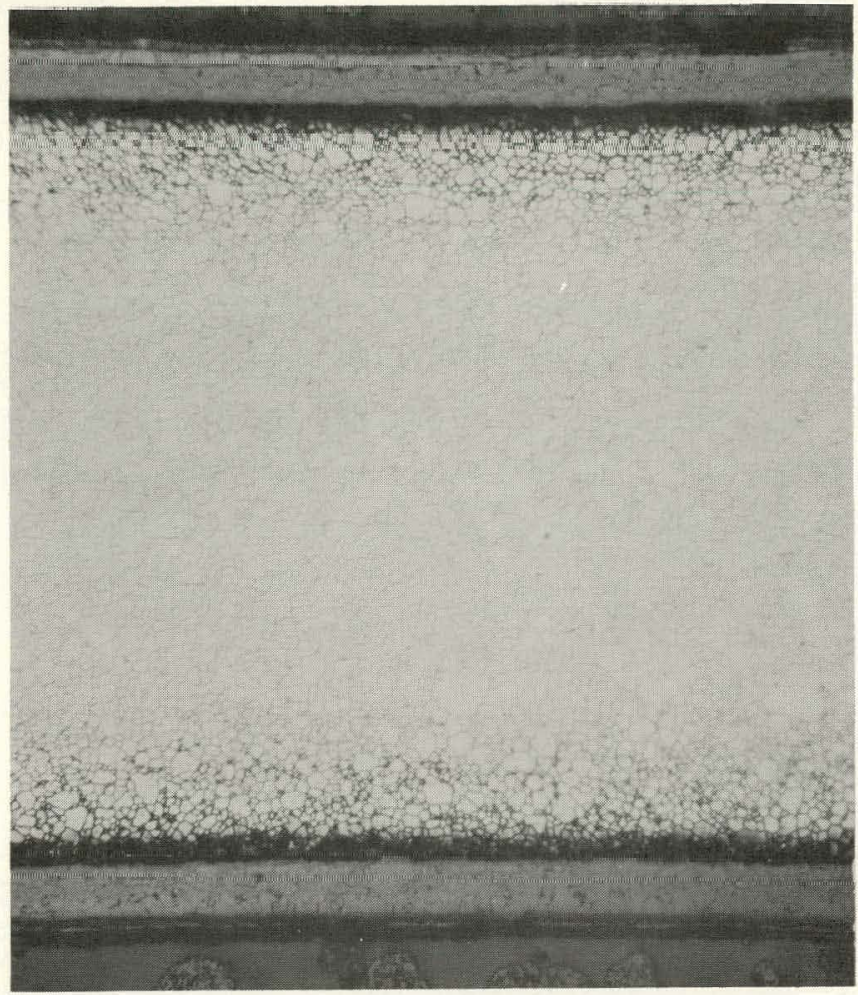

Figure 4. Photomicrograph of a Cross-Section Through Disk of Incoloy Alloy 800. The Cross-Section is Near Top of Disk Shown in Figure 3, 100X

Figure 5. Photomicrograph of Incoloy Alloy 800 Disk in Figure 4 Showing Corrosion Product Layers and Substrate Metal. $200 x$

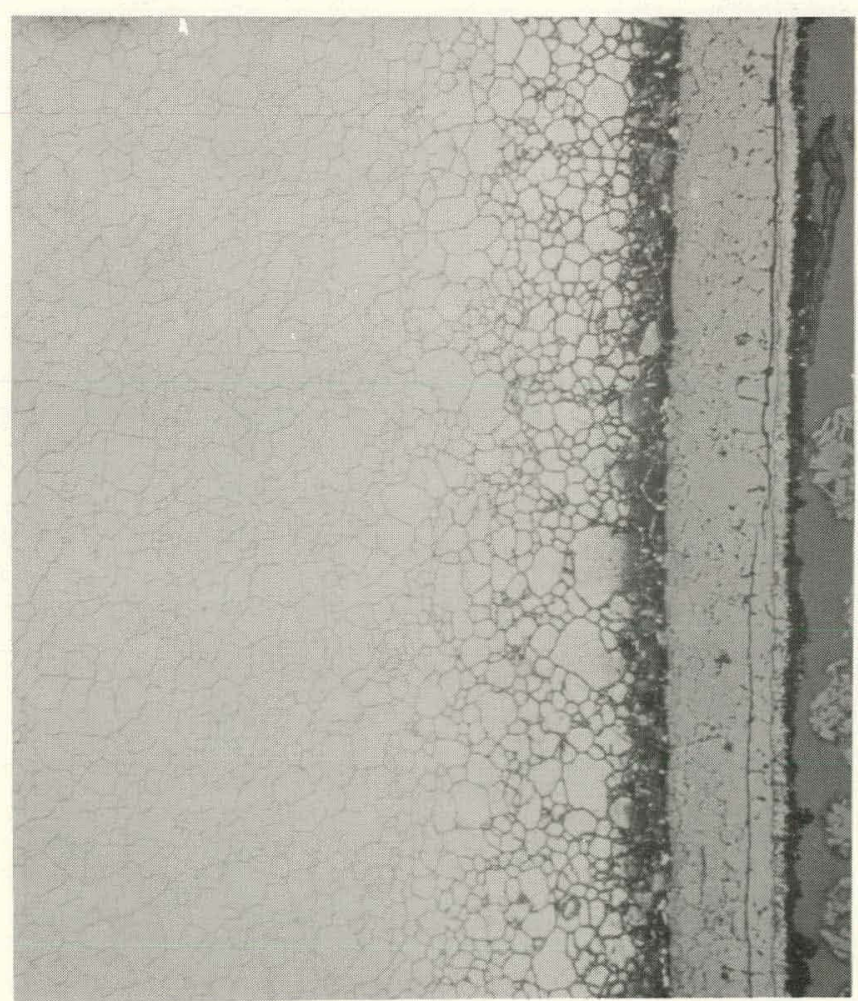

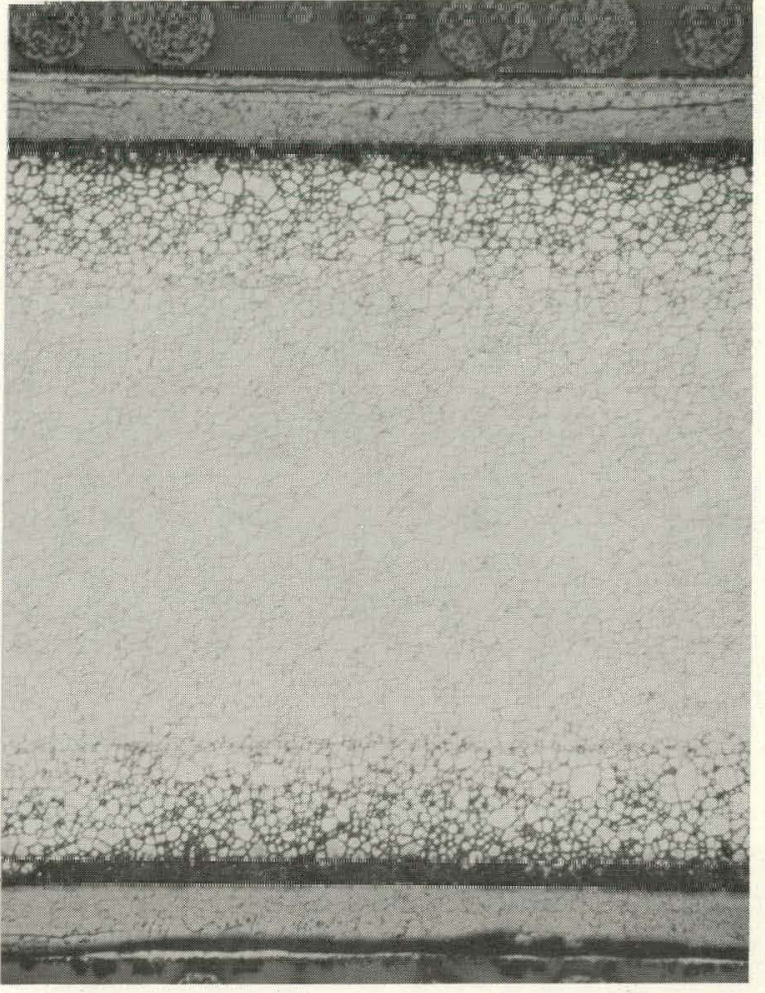

Figure 6. Photomicrograph of a Cross-Section Through Middle of Incoloy Alloy 800 Disk Shown in Figures 3-5. 100X

Figure 7. Photomicrograph of Incoloy Alloy 800 Disk in Figure 6 Showing Corrosion Product Layers and Substrate Metal. 200X

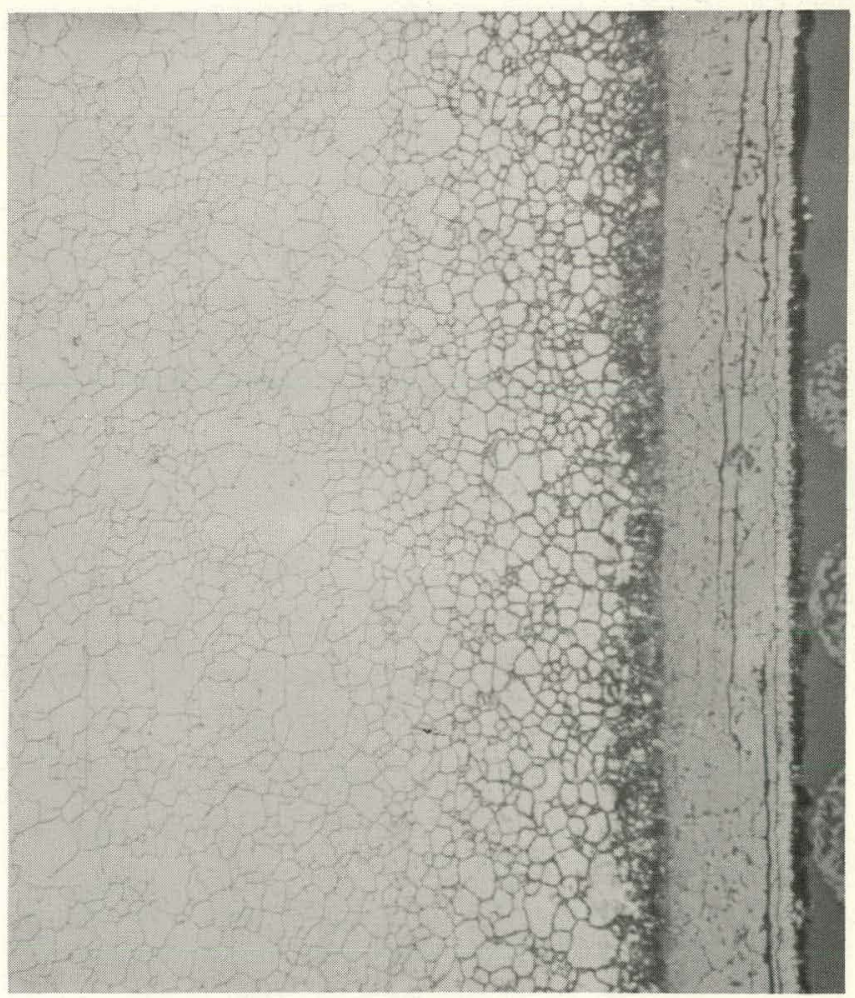




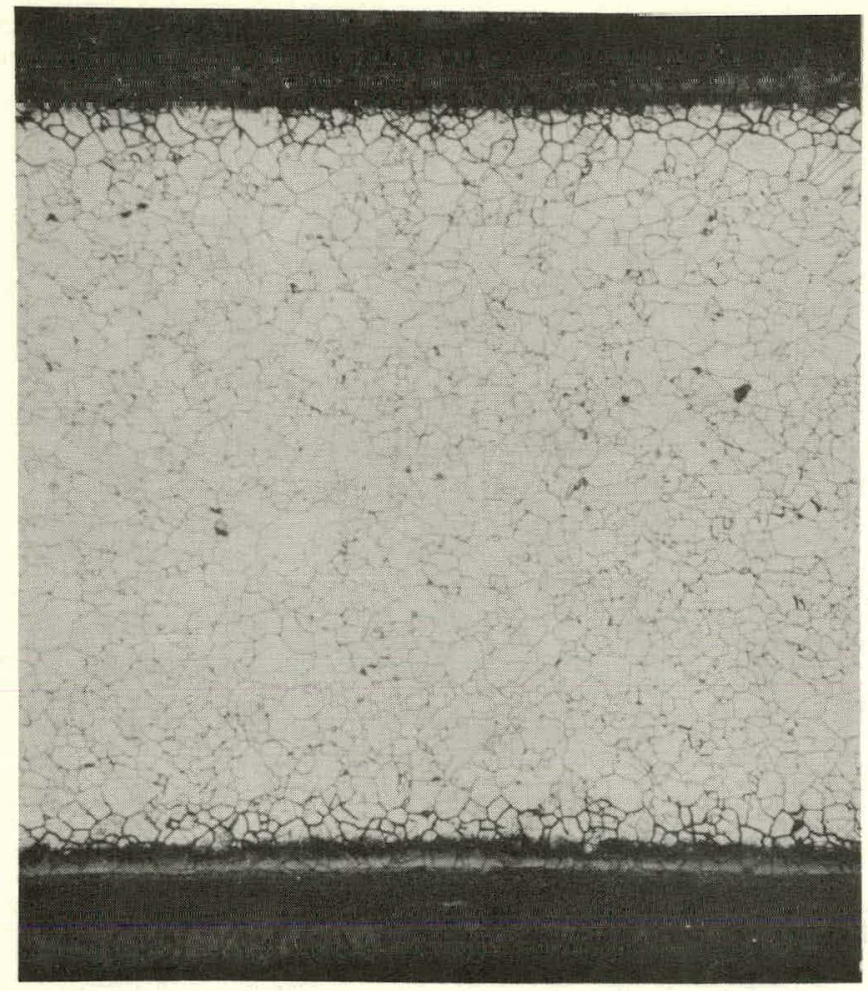

Figure 8. Photomicrograph of a Cross-Section through 321 Stainless Steel Disk Showing More Heavily Corroded Region Near Top of Disk in Figure 3. 50X

Figure 9. Photomicrograph of Same Region Shown in Figure 8 Showing Corrosion Product Layers and Substrate Metal. $200 x$

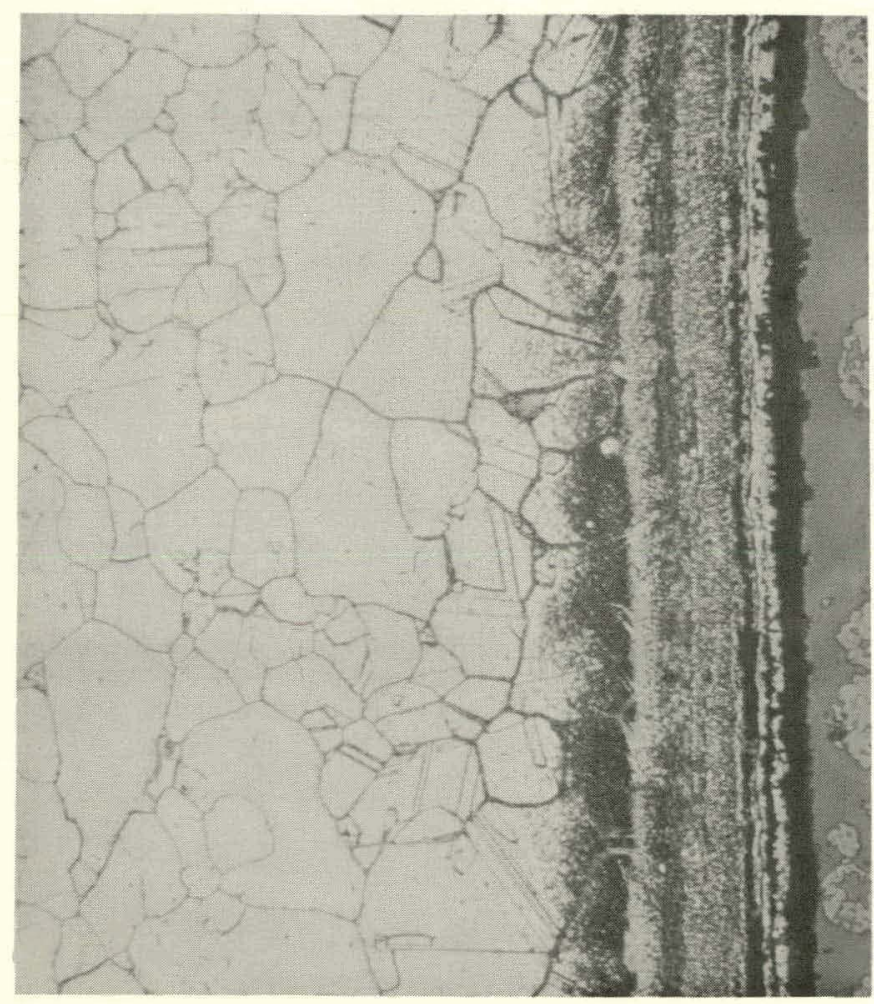

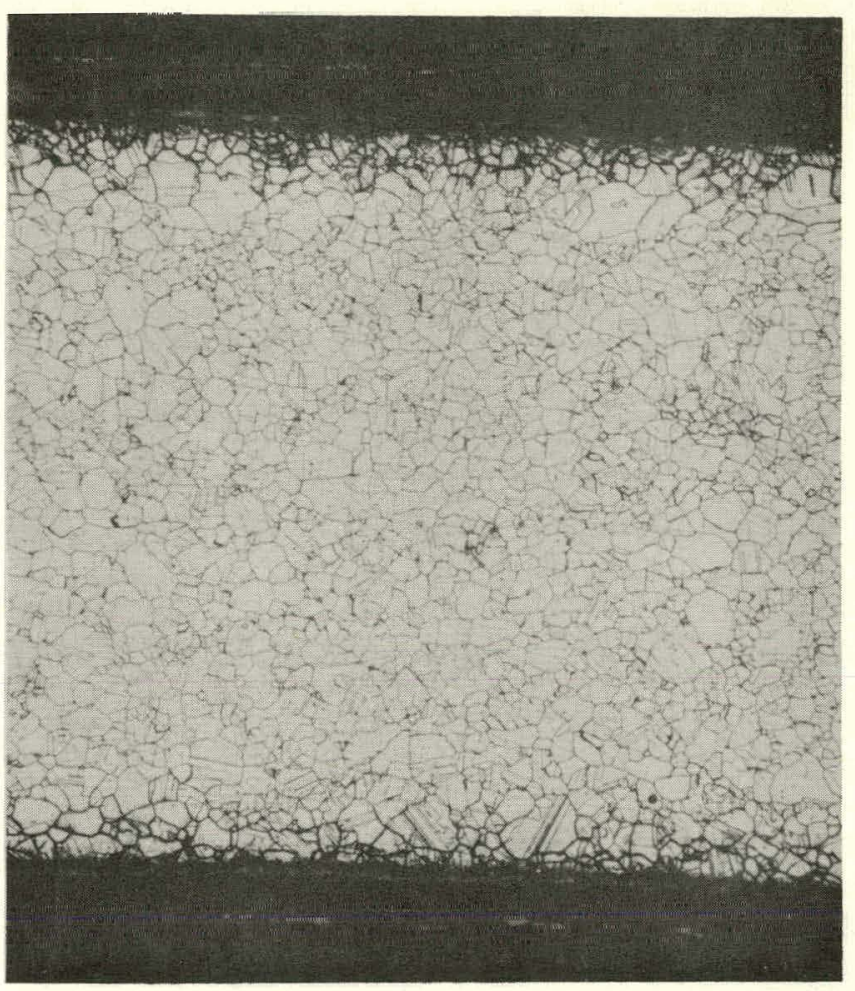

Figure 10. Photomicrograph of a Cross-Section through 321 Stainless Steel Disk Showing Slightly Corroded Region Near Middle of Disk in Figure 3 . $50 \mathrm{X}$

Figure 11. Photomicrograph of Same Region Shown in Figure 10 Showing Corrosion Product Layers and Substrate Metal. $200 x$

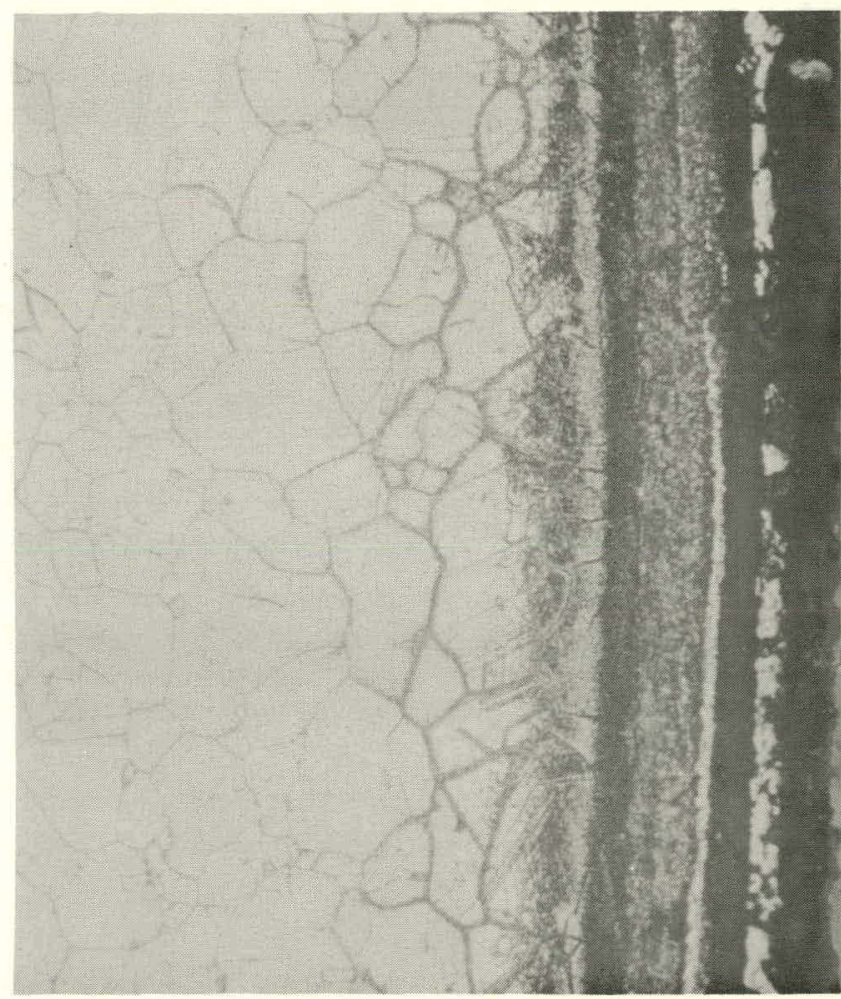




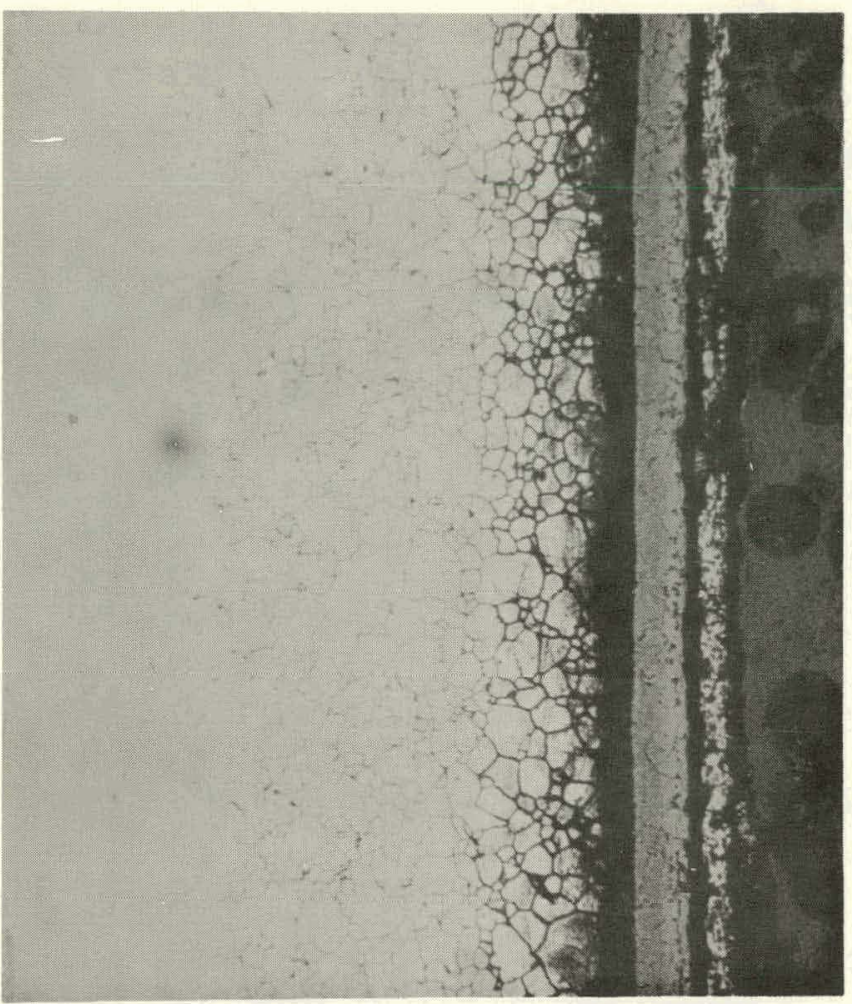

Figure 12. Corrosion Product Layers and Substrate Metal of Incoloy Alloy 800 Stressed Specimen after 60 Days in Fused Salt Bath. $100 \mathrm{X}$

Figure 13. Corrosion Product Layers and Substrate Metal of $\mathbf{3 2 1}$ Stainless Steel Stress Specimen after 60 Days in Fused Salt Bath. $100 \mathrm{X}$

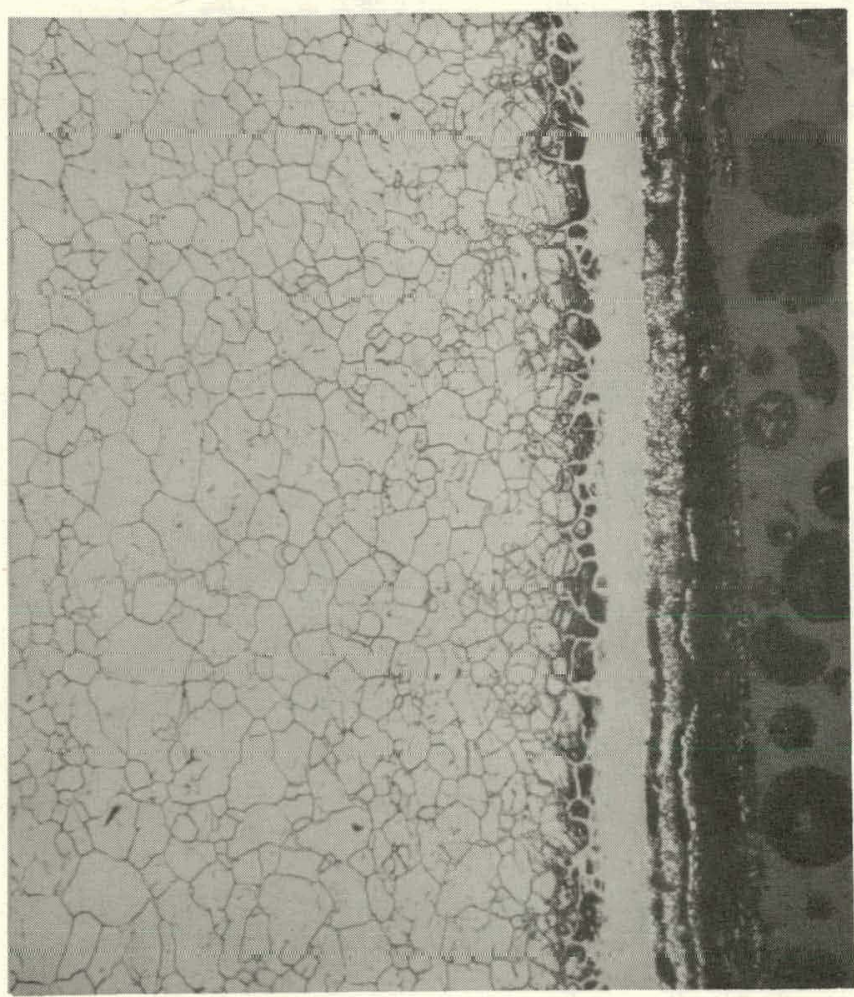

The Incoloy alloy 825 disks exhibited marginal average corrosion rates in the fused salt ( 2 and 4 mpy); however, the disks were severely attacked on the upper, air-exposed surfaces as shown in Figure 3. Thus, the 2 and 4 mpy average corrosion rates represent much less penetration than that which occurred in these regions of localized corrosion.

The increase in carbon content in the Incoloy alloy 800 and 321 stainless steel bend specimens shows that the fused salt bath is carburizing with respect to these two alloys.

The Incoloy alloy 800 disks gained over $600 \mathrm{mg}$ (40 mg $/ \mathrm{dm}^{2} /$ day) during the 30 -day test period. The disks were placed back into the fused salt environment for 15 additional days and then re-weighed. An 86 -mg weight gain $\left(11 \mathrm{mg} / \mathrm{dm}^{2} /\right.$ day $)$ was measured for the second (15 day) exposure period which indicates that a protective corrosion product layer had formed.

Metallographic examination of the Incoloy alloy 800 disks (Figures 4-7) shows an adherent corrosion product layer and possible grain boundary sensitization. Figures 5 and 7 show that grain boundary precipitation occurred to a depth of 4 to 6 mils but no precipitation occurred past this surface region. The adherent corrosion product layer is 3-mils thick.

The 321 stainless steel disks exhibited corrosion rates of less than 2 mpy. The disk surfaces exhibited a uniform appearance of general corrosion with no scaling or extoliation. The black, adherent corrosion product layer on the disk surface was about 3 -mils thick. The fused salt bath temperature was $640 \pm 20^{\circ} \mathrm{C}$ which is within the sensitization range for austenitic stainless steels. ${ }^{2}$ Metallographic examination of the disks (Figures 8-11) showed apparent grain boundary sensitization to a depth of 5 to 9 mils. Figures 8 to 11 appear to show that a small amount of sensitization has occurred throughout the 321 stainless steel disk in addition to the heavy sensitization near the surfaces of the disks. Although 321 stainless steel contains sufficient titanium to tie up the carbon initially present in the steel, the additional carbon from the salt bath could result in sensitization. However, in carburizing environments which result in sensitization, the 321 stainless steel may still be an acceptable fabrication material provided that the sensitization does not lead to rapid intergranular corrosion. It should be noted that the apparent sensitization is based on metallographic results which show precipitates along the grain 
boundaries which are assumed to be chromium carbides.

None of the stressed Incoloy alloy 800 or 321 stainless steel specimens exhibited failure during the fourpoint bend stress-corrosion tests. This was expected since the stress-corrosion cracking of austenitic stainless steels requires at least $2.5 \mathrm{wt} \%$ moisture in the fused salt ${ }^{3}$ and the $640^{\circ} \mathrm{C}$ fused salt used for the test.s was anhydrous.

Figures 12 and 13 show transverse cross sections through the stress-corrosion specimens in the region of maximum applied tensile stress. These photomicrographs are similar to those obtained from the disks after the corrosion tests (Figures 4-11). In Figure 12, the dark region between the corrosion product layer and the substrate metal is a dark corrosion product and not a void. The 321 stainless steel specimen shown in Figure 13 suffered some intergranular corrosion to a depth of 2 or 3 grains past the major metal-corrosion product interface. This intergranular penetration does not appear to be deep enough to be detrimental and may have the beneficial effect of making the corrosion product layer more adherent.

No significant intergranular corrosion attack was observed for Incoloy alloy 800 or 321 stainless steel in the sensitized areas as might be observed in an acid media. ${ }^{4}$ Therefore, the minimal sensitization observed in both alloys probably would not be a problem in the fused salt environment.

\section{CONCLUSIONS}

Of the ten alloys tested, only Incoloy alloy 800 and 321 stainless steel exhibited satisfactory corrosion resistance to the fused salt. Neither Incoloy alloy 800 or 321 stainless steel exhibited any sensitivity to stress-corrosion cracking. Both alloys were carburized by the fused salt and both alloys were apparently sensitized after immersion in the fused salt.

Either Incoloy alloy 800 or 321 stainless steel would be suitable for fabricating the fused salt annealing tank.

\section{REFERENCES}

1. “Stress Corrosion Testing," STP No. 425, ASTM, Baltimore (1967).

2. M. G. Fontana and N. D. Greene, "Corrosion Engineering," McGraw-Hill Book Company, New York (1967).

3. P. R. Rhodes, "Mechanism of Chloride Stress Corrosion Cracking of Austenitic Stainless Steels," Corrosion, 25,462 (1969).

4. C. L. Angerman and P. M. Kranzlein, "Preferential Corrosion of Stabilized Stainless Steel Welds," Transactions of the ASM, 53,433 (1961). 